\title{
Mitigation needs adaptation: Tropical forestry and climate change
}

\author{
Manuel R. Guariguata • Jonathan P. Cornelius • \\ Bruno Locatelli • Claudio Forner • \\ G. Arturo Sánchez-Azofeifa
}

Received: 29 August 2007 / Accepted: 17 December 2007 /

Published online: 10 January 2008

(C) The Author(s) 2007

\begin{abstract}
The relationship between tropical forests and global climate change has so far focused on mitigation, while much less emphasis has been placed on how management activities may help forest ecosystems adapt to this change. This paper discusses how tropical forestry practices can contribute to maintaining or enhancing the adaptive capacity of natural and planted forests to global climate change and considers challenges and opportunities for the integration of tropical forest management in broader climate change adaptation. In addition to the use of reduced impact logging to maintain ecosystem integrity, other approaches may be needed, such as fire prevention and management, as well as specific silvicultural options aimed at facilitating genetic adaptation. In the case of planted forests, the normally higher intensity of management (with respect to natural forest) offers additional opportunities for implementing adaptation measures, at both industrial and smallholder levels. Although the integration in forest management of measures aimed at enhancing adaptation to climate change may not involve substantial additional effort with respect to current practice, little action appears to have been taken to date. Tropical foresters and forest-dependent communities appear not to appreciate the risks posed by climate
\end{abstract}

M. R. Guariguata $(\bowtie)$

Center for International Forestry Research, P.O. Box 6596 JKPWB, Jakarta 10065, Indonesia e-mail: m.guariguata@cgiar.org

J. P. Cornelius

Agroforestry and Novel Crops Unit, School of Marine and Tropical Biology, James Cook University, P.O. Box 6811, Cairns, Queensland 4870, Australia

B. Locatelli

CIRAD UPR Forest Resources, Montpellier, France, and Global Change Group, CATIE, 7170 Turrialba, Costa Rica

C. Forner

Secretariat of the United Nations Framework Convention on Climate Change, Martin Luther King St., 853175 Bonn, Germany

G. A. Sánchez-Azofeifa

Department of Earth and Atmospheric Sciences, University of Alberta, Edmonton, Alberta T6G 2E3, Canada 
change and, for those who are aware of them, practical guidance on how to respond is largely non-existent. The extent to which forestry research and national policies will promote and adopt management practices in order to assist production forests adapt to climate change is currently uncertain. Mainstreaming adaptation into national development and planning programs may represent an initial step towards the incorporation of climate change considerations into tropical forestry.

Keywords Climate change - Adaptation - Tropical forests · Tropical tree plantations · Natural forest management

\section{Introduction}

The relationship between tropical forests and global climate change has received considerable scientific as well as political attention over the last decades (e.g. Shukla et al. 1990; IPCC 1996; Markham 1998; Lewis 2006). However, discussions have focused disproportionately on mitigation (i.e. reducing emissions or else enhancing sinks of greenhouse gases; IPCC 2000), while much less emphasis has been placed on how management activities might help tropical forest ecosystems adapt to climate change in order to maintain the provision of goods and services to society. The lack of attention to this theme has continued in recent international meetings on forests and global climate change, which either have excluded the tropics (e.g. IISD 2006), or have not explicitly considered the need to adjust tropical forestry practices in the context of a changing climate (e.g. Innes et al. 2005, pp. 72-104; Parrotta et al. 2005).

This omission is understandable. First, it reflects the wide appreciation of the critical role of tropical forests as globally significant standing stocks of above- and below ground carbon (Dixon et al. 1994). Second, atmospheric carbon sequestration through tree planting is the only currently eligible land use change activity for developing countries within the Clean Development Mechanism (CDM) of the United Nations Framework Convention on Climate Change (UNFCCC) for which there is an international carbon market and where Certified Emission Reductions are traded. By contrast, investment in adaptation to climate change is largely a national concern and may not yield immediate economic return. Because of associated uncertainties, the assessment of the future contribution of a given adaptation activity can also be speculative (Callaway 2004). Furthermore, in many countries climate change is perceived as a relatively minor threat to forests compared with socioeconomically driven causes of land-use change such as pasture expansion, illegal logging, or otherwise uncontrolled forest conversion (Lambin et al. 2001). Finally, in cases where forests and forestry make, or are perceived to make, minor contributions to national economies (e.g. Keller et al. 2007), national governments may be more concerned with ensuring adaptation in other productive sectors such as agriculture or water supply.

There are, however, reasons to consider why tropical forestry may need to include climate change adaptation. First, tropical forests make important contributions to rural livelihoods (Sunderlin et al. 2005) and, partly because of this, natural resource users in developing countries are frequently considered highly vulnerable to climate change (Adger et al. 2003; Thomas and Twyman 2005). The enhancement of the adaptive capacity of both natural and planted forests may help to decrease the vulnerability of those whose livelihood depend on forest goods and services, especially the poorest (Innes and Hickey 2006). Second, without management for adaptation, the current potential of tropical forests to both remove and store atmospheric carbon may diminish thus feeding a positive feedback of 
carbon emissions (e.g. Gitz and Ciais 2004). Third, although only $7 \%$ of the $352 \mathrm{M}$ ha of natural forests that the International Tropical Timber Organization producer countries have set aside for sustainable production is being used that way (ITTO 2006), this figure is expected to increase. In Brazil alone, up to 50M ha of Amazonian forest are planned to be managed under sustainability criteria through the next decades (Verissimo et al. 2002; Schulze et al. 2008). The success of this expanded effort in sustainable management may depend on the implementation of adaptation measures to counteract already evident impacts of climate change on forest structure and function in this region (Lewis et al. 2006). Fourth, there is a global trend towards increased timber demand from tree plantations, including those in the tropics (Varmola et al. 2005; FAO 2006a). Under the current trends of global climate change, tropical timber plantations are expected to take a larger share of the global wood market than mid-to-high latitude plantations (due to anticipated dieback; Sohngen et al. 2001). Tropical plantations that are poorly adapted to future conditions may be unable to meet future demand.

In this paper we examine how forestry practices can contribute in maintaining or enhancing the adaptive capacity of tropical production forests to global climate change. We suggest the need for reassessing current practice in light of observed and projected changes in climate and climate variability in tropical forest regions. We also identify obstacles and opportunities for integrating tropical forest management in broader climate change adaptation. We will illustrate all of our points with concrete examples from the American tropics. By "adaptive capacity" we mean the ability of a system to adjust to climate change, to moderate potential damages, to take advantage of opportunities, or to cope with the consequences (IPCC 2001).

\section{Managing production tropical forests under a changing climate}

Since the mid-1970s, warming trends in tropical forest regions have averaged $0.26^{\circ} \mathrm{C}$ per decade, consistent with global temperature rises linked to greenhouse gases; precipitation appears to have decreased, although these changes appear more drastic in northern tropical Africa than Asia or the Amazon (Malhi and Wright 2004). Dramatic atmospheric change has also taken place in some localities (e.g. Pounds et al. 2006). Overall, precipitation anomalies as predicted by different climate models point to likely decreases in certain tropical areas as well as likely increases in others (Neelin et al. 2006). In particular, projected changes in annual precipitation for the American tropics include a decrease in Central America and large uncertainties for northern South America and the Amazon; however, in some regions there is qualitative consistency among climate simulations (e.g. increased rainfall in Ecuador and northern Perú; Christensen et al. 2007). In addition, the frequency and intensity of extreme weather events (tropical storms, hurricanes, drought) are also expected to increase during this century partially due to human influence (Salinger 2005; IPCC 2007a). For example, both the recurrence and intensity of the El Niño Southern Oscillation (ENSO), the main driver of interannual variation in temperature and precipitation across most of the tropics, have increased during the last century with concomitant record droughts since 1976 (Malhi and Wright 2004), probably exacerbated by global warming (Timmermann et al. 1999; Federov and Philander 2000). Adaptation to climate change through forest management will have to include anticipatory actions such as reducing the sensitivity of the system, altering its exposure to the effects of change, and enhancing its ability (resilience) to recover after disturbance (Adger et al. 2005).

Although tropical forests have adapted to probably even more drastic climatic change over the last several thousands of years before the present (e.g. Colinvaux et al. 1996, 2000; 
Morley 2000), the pace of current changes in the global climate as well as the concurrent imposition of anthropogenic stressors (recently reviewed in Laurance and Peres 2006) may be beyond their natural adaptive capacity. It is generally assumed that a given degree of forest structural and biological diversity at various scales is necessary for maintaining the adaptive capacity of forests to environmental change (Noss 2001; Drever et al. 2006). One approach to achieve this is by applying reduced impact logging practices (RIL) which greatly minimize the effects of timber harvesting on vegetation, soils, and water (Dykstra and Heinrich 1996; Johns et al. 1996; Sist 2000). However, complementary, on-site and offsite approaches may be needed. Next we discuss specific silvicultural practices to enhance the adaptive capacity of production forests under a changing climate and also mention key institutional and policy interventions that may facilitate the inclusion of climate change into tropical forest management. We structure our discussion in the context of natural forest and tree plantations (summarized in Table 1).

\section{Natural forest management}

\subsection{Facilitating adaptive capacity of timber species}

Natural forest management in the tropics typically involves the harvesting of timber trees above a minimum diameter on a polycyclic basis. This implies that successive generations of the species of interest will be derived from adult progenitors in situ. Each individual that reproduces will have both experienced and (to date) survived the environmental conditions associated with past or current climate change. If the survival - or failure to survive - of these individuals (and their progeny) is related to their genotypes, then, by definition (Grant and Grant 1995), natural selection will have occurred and adaptation will have taken place. The response to natural selection depends on the magnitude of phenotypic variation in adaptive traits, the degree to which it is under genetic control and the intensity of the selection (Falconer 1989; McKay and Latta 2002). There are a number of practical options to maximize this response.

One is to maximize population sizes when selection pressure for survival is strongest; i.e. the seed and seedling stages. It may be that one cause of the relatively high local adaptation shown by many forest trees (Petit and Hampe 2006) is their high fecundity in comparison with other plants (Le Corre and Kremer 2003). High fecundity implies that those trees that survive to reproductive age (or harvest age) represent a small proportion of an initially large pool of seedlings, further implying that they have undergone a high selection intensity. To ensure high juvenile population sizes and thus promote high genetic variation at this stage, a few treatments can be applied such as controlled burning to enhance seedling establishment (e.g. in Central American closed-cone pine forests; Wolffsohn 1984), thinning (possibly as a part of controlled logging) aimed at stimulating crown development and eventual fruiting of seed trees (e.g. Guariguata and Saenz 2002), and the creation of canopy or ground disturbance for the regeneration of light demanding timber species (Fredericksen and Pariona 2002; Snook and Negreros-Castillo 2004; Grogan et al. 2005). Other options are to maximize the number of seed trees to be retained and harmonize the timing of tree harvesting to follow seed dispersal (e.g. Grogan and Galvão 2006); for dioecious species, retaining similar numbers of adult male and female trees to ensure reproduction and maintain genetically effective population sizes (Yeh 2000).

The natural distributions of many neotropical tree species cover a wide range of variation in precipitation and temperature (Greaves 1978; Pitman et al. 2001; Hodge et al. 
Table 1 A broad classification of approaches and actions that may be needed for adapting tropical forest management for timber production to climate change

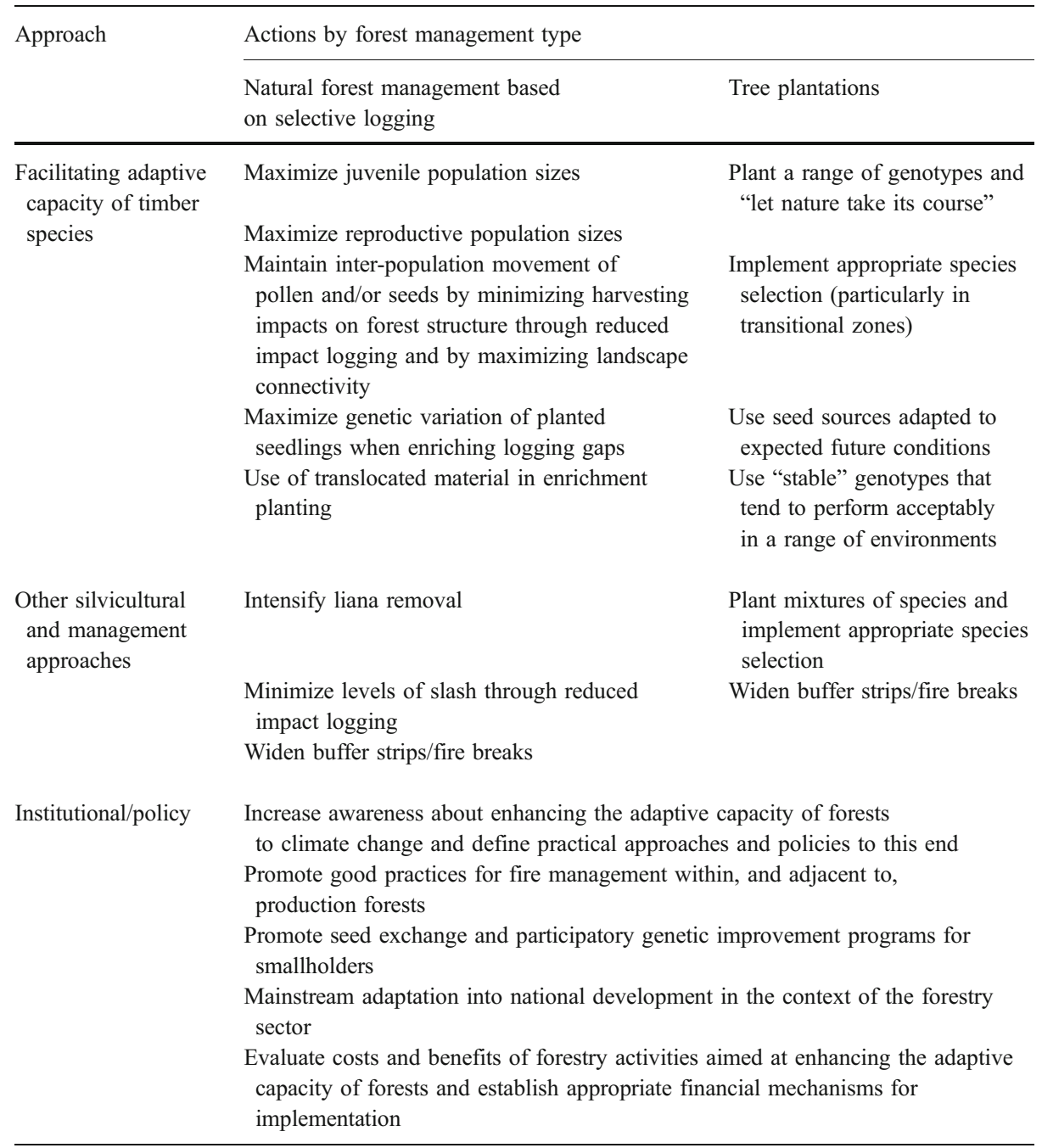

2002; Vozzo 2002; Cordero and Boshier 2003), which suggests that they have the genetic variation necessary to cope with environmental change within and possibly beyond these limits. However, common-garden studies have found marked genetic differentiation in quantitative traits between populations from specific climatic regions (e.g. Cornelius et al. 1996; Boshier and Henson 1997; Navarro et al. 2002). This implies that while, within the overall gene pool of a species, the potential for adaptation may exist, any one individual population is unlikely to have this potential. That is, the alleles needed for adaptation to climate change in a specific region may be present only, or in much higher frequencies, in populations from other regions. The problem then becomes one of "getting the variation where it is needed". This can be approached by enhancing or maintaining natural migration through landscape connectivity (maintenance of forest cover, tree corridors, trees outside 
forests). This would be relevant in the case where marked environmental variation (and, by implication, possible genetic differentiation) is found at a relatively small geographic scale, e.g. in mountainous areas or for species present both in riparian and neighboring "upland" forest. In areas characterized by relatively uniform temperature and rainfall regimes, the effectiveness of this strategy in the face of current rapid climate change is questionable, because useful alleles at high enough frequencies may not be found sufficiently close to target populations. In this case, the only feasible approach may be translocation through planting, as suggested by Ledig and Kitzmiller (1992).

\subsection{Other silvicultural and management approaches}

Modified silvicultural activities in natural forests may be required in the context of climate change. For example, long-term increases in liana abundance have been recorded in many undisturbed neotropical forests. These changes have been attributed to faster growth induced by enhanced levels of atmospheric carbon and ambient temperature (Phillips et al. 2002; Wright et al. 2004). To the extent that liana abundance is driven by these causes, this may imply more lianas over time. Liana removal from crop trees prior to harvest is generally carried out in order to minimize collateral tree damage in forests managed under RIL practices (Johns et al. 1996; Sist 2000). An adaptation option would require additional input for their control by logging crews at successive rotations which could also minimize growth declines or else mortality of liana-infested timber trees (Phillips et al. 2005). In the case of trees, evidence of climate-driven, accelerated tree growth rates have also been detected across the Amazon basin over the last decades (Lewis et al. 2004; but not in Central America; Feeley et al. 2007). Increased productivity in the Amazon could shorten rotations between successive harvests (which currently span no less than 40years in Amazonian forests; Valle et al. 2006) but it may also favor, over the long term, dominance of fast-growing timber species (e.g. Laurance et al. 2004). The refinement of silvicultural techniques to generate levels of commercial regeneration within this ecological guild may be needed.

Enrichment planting can provide opportunities for maximizing genetic variation of selected timber species at the stand level, particularly those susceptible to commercial extinction in the absence of post-logging silvicultural interventions (Fredericksen and Putz 2003). For example, in Brazil it is now mandatory to plant mahogany (Swietenia macrophylla) seedlings in felling gaps after extraction of adult trees from the site (Grogan and Barreto 2005). Other high-value Amazonian timber species that show naturally low seedling densities under closed canopy are also in need of post-logging enrichment planting to ensure adequate stocking between harvest rotations (Schulze 2008).

Fire management in the context of a changing climate also deserves attention. Forest fires associated with extreme droughts (further projected to increase in neotropical forests; Cox et al. 2004; Nepstad et al. 2004; Scholze et al. 2006) like those during 2005 in the Western Amazon (Brown et al. 2006) can be countered through RIL practices which, in comparison to conventional logging, decrease the vulnerability of the forest to ground fire through a reduction of the size of both felling gaps (usually the most fire susceptible areas) and fuel loads (Holdsworth and Uhl 1997; Blate 2005). However, focusing only on the forest is unlikely to succeed. The recent increase in frequency and extent of forest fires in the Amazon may not be only due to the effects of more intense ENSO-related droughts but also to direct anthropogenic influences at forest edges (Barlow and Peres 2004; Laurance 2004). In fact, fires that spread from adjacent pastures seem the overriding cause of forest burning across the Amazon (Cochrane 2001), including those intruding into timber concessions (e.g. Pinard et al. 1999). 


\section{Tree plantations}

In the case of planted forests, the range of approaches for enhancing adaptive capacity to climate change is perhaps wider than of natural forests, as both genetic material and silvicultural treatments can be adjusted more readily (Lamb et al. 2005). These are discussed below. Yet the most fundamental measure is the choice of appropriate species. It is useful to consider species-site matching as a two-step process. First, the selection of a group of species broadly appropriate for a given climatic zone. These could be (for the neotropics), "high altitude species" (e.g. Alnus acuminata, Cupressus lusitanica, Eucalyptus globulus), "seasonally-dry zone species" (e.g. Bombacopsis quinata, Swietenia macrophylla, Tectona grandis), "wet zone species" (e.g. Carapa guianensis, Eucalyptus deglupta, Vochysia guatemalensis). Second, the selection of species for specific conditions within that zone (e.g. Cordia alliodora for soils with low aluminum saturation, B. quinata for vertisols, Calycophyllum spruceanum for seasonally flooded areas). In general, we consider it unlikely that climate change considerations would, in the short term, lead to changes in species selection (particularly perhaps at the first step), because within the period of a fastwood rotation (typically 10years or less), conditions would not change enough to shift the group of suitable species towards that more suitable for another location. However, current species choice should be regularly reviewed, particularly in transitional environments and longer-rotation hardwood species. It is also important to note that the challenge posed by climate change underlines the importance of careful selection even for current conditions; species that are poorly adapted at present to a given planting site are likely to be ill-prepared to deal with stress from future climate change.

\subsection{Facilitating adaptive capacity of timber species}

As outlined some time ago by Ledig and Kitzmiller (1992), taking account of climate change for seed sourcing may require some departure from current practice. The generally accepted "current wisdom" continues to be that, where information from genetic tests is lacking, "local seed is best". Under climate change, this may no longer be the case, as local seed sources are more likely to be adapted to historic, rather than near-current (i.e. the next planting season) and future conditions; one response under this is to choose seed sources expected to be better adapted. For example, Sáenz Romero et al. (2006) assessed the genetic variation of populations of Pinus oocarpa, an economically important timber species in Mexico, across an altitudinal gradient. They concluded that managers should assist $P$. oocarpa populations to adapt whenever carrying out planting programs by moving seed genotypes at given intervals upwards in anticipation of projected trends of increasing temperature (IPCC 2007b).

Similarly, results of provenance trials may suggest specific actions. Coastal provenances of Pinus caribaea var. hondurensis show greater structural stability when exposed to cyclones (Gibson et al. 1983; Nikles et al. 1983), whilst provenances of the same species from high rainfall locations have shown lower survival than provenances from lowerrainfall origins when both are planted on relatively dry sites (Hodge et al. 2001). However, it may not always be clear which sources represent the best balance between adaptation to near-current and future conditions. Two responses to this uncertainty are possible. First, generalist ("stable", in breeders' terminology) genotypes can be used, i.e. those which show wide adaptability to a range of conditions; this option is only feasible where field tests exist and where they have sampled a wide enough range of conditions. Second, germplasm mixtures that may contain very high genetic variation may be used. For example, Ledig and Kitzmiller (1992) suggested using a mixture of provenances (e.g. the local seed sources and 
sources expected to be adapted under a range of climate change scenarios). Poorly adapted, inferior trees would be removed during thinning or through differential early mortality. This approach recognizes the uncertainty present in the projections of future climate conditions and takes advantage of conventional silvicultural practice in order to ensure well-adapted trees for the final harvest. As in the case of species selection, the urgency of implementation of such approaches may be less in the case of fast-growing species as, at least in the industrial context (see below), current germplasm may be replaced in the short-medium term through replanting with other sources.

In considering current practice and the potential for applying germplasm selection and development, it may be useful to distinguish industrial tree planting and smallholder tree planting. In the particular case of industrial plantations, approaches to adaptation to climate change based on germplasm selection and development are more likely to be implemented because industrial forestry is generally much better funded than smallholder forestry. Although we have been unable to identify any modifications of neotropical industrial tree breeding aimed specifically at adaptation to climate change, existing tree improvement programs that continuously incorporate new selections would, nevertheless, secure the use of germplasm one generation, at most, 'behind' current climatic conditions; in other words, it will permit a delayed 'tracking' of climate change. At the same time, there are clear deficiencies in current management of genetic resources by some private enterprises. For example, one medium-sized enterprise in Pará, Brazilian Amazon, is basing much of its reforestation efforts on only two clones of Eucalyptus urograndis developed under the quite different ambient conditions of Minas Gerais, some 1,600km to the south (J.P.C., personal observation, February 2007). In view of uncertainty over future climatic changes, such practices appear to be short-sighted.

The types of responses feasible in smallholder forestry may be different than in industrial forestry and reflect the fact that smallholders plant trees in various situations and for various reasons. One is externally led tree planting programs; that is, sponsored or promoted by government and non-government organizations where farmers often receive free or subsidized seed or seedlings. In these programs, germplasm is often sourced with little or no technical criteria and without any provision or plan for replacement in subsequent rotations. New germplasm will most likely come from the same germplasm sources as before (Simons et al. 1994). When smallholders plant trees under their own initiative, they also often use germplasm collected on-farm or from neighboring farms (e.g. Weber et al. 1997). Even under stable climatic conditions, such practices may lead to use of germplasm that is poorly adapted or genetically depauperate (e.g. Inga edulis in Amazonia; Hollingsworth et al. 2005). When technical assistance is being offered under both situations, managers would be well-advised to ensure that initial (founder) populations include adequate genetic diversity, both by maximizing number of seed trees and using provenance mixtures (as discussed above).

\subsection{Other silvicultural and management approaches}

There is evidence that use of mixed species plantings over monocultures may reduce vulnerability of the system over the long-term (Jactel et al. 2005; Kelty 2006). Mixes of tree species with contrasting phenologies, different below- and above ground architecture, and/or nitrogen-fixing ability can increase biomass production compared to monocultures (Lamb 1998; Petit and Montagnini 2006) while providing economic risk reduction and earlier financial returns (Hartley 2002). One of the largest monospecific tree plantations in the American tropics (about 0.6M ha of Pinus caribaea var. hondurensis in Venezuela) suffered 
massive (fungus-induced) tree mortality mediated by water stress during the very intense 1997 El Niño drought (Cedeño et al. 2001). In another (extra-tropical) example, after largescale, climate-mediated destruction of forests, including coniferous monocultures in France during 1999, new silvicultural practices to increase stand diversity and hence to improve adaptive capacity were recommended (Bastien et al. 2000). Although tree monocultures are easier to manage and simplify both nursery and harvesting costs (Kelty 2006), current concerns about climate change and long-term sustainability may enhance awareness and further stimulate the interest of industrial foresters in mixed-species plantations, an option which they have largely disregarded (Nichols et al. 2006).

\section{Institutional and policy approaches}

In addition to the technical approaches discussed above, institutional and policy interventions will be needed in order to facilitate the incorporation of climate change into tropical forestry. One of these relates to dissemination of practical guidance. There are relatively detailed UNFCCC guidelines for estimating and reporting greenhouse gas emissions and carbon dioxide removals associated with different land uses, land-use changes and forestry activities (Penman et al. 2003), but little or no published guidance on adaptation to climate change in tropical production forests. The available guidance to assess impacts and vulnerability of forests to climate change in order to delineate adaptation options is both generic and outdated (e.g. Carter et al. 1994; Scholes and Linder 1998) while recent guidance on developing broad adaptation strategies (e.g. Lim and SpangerSiegfried 2005) does not include forestry activities within its illustrative set of examples. Probably because of these deficiencies, forestry activities in general, and climate-mitigation forestry projects in particular, rarely acknowledge that tree planting efforts may be vitiated if for example a plantation is poorly adapted to the climate changes it is supposed to mitigate. Although some global initiatives for independent carbon forestry certification are fostering the inclusion of adaptation measures (e.g. the Climate, Community, and Biodiversity Project Design Standards (CCBA 2005)), these still do not mention specific practice. A more explicit dissemination of tools and approaches for enhancing the adaptive capacity of natural and planted forests seems necessary.

Enhancing the adaptive capacity of smallholder planted forests to future climate conditions may also necessitate targeted assistance. Smallholder tree farmers unable to supplement by themselves their local germplasm with strategically selected germplasm from other, perhaps distant tree populations, will be in need of technical help. Relatively large-scale tree improvement programs focused on smallholders, such as those implemented in Costa Rica (e.g. Mesén et al. 1993) or Perú (e.g. Weber et al. 2001; Cornelius et al. 2006) can be an option but only for a few of the highest priority species of the tens or hundreds used by them (Sotelo Montes and Weber 1997). For a wider set of species, smaller scale, local participatory tree genetic improvement (Simons and Leakey 2004) offers another opportunity. The exchange of tree germplasm through "seed fairs" such as those organized in Madre de Dios, lowland Perú (P. Casanova, Asociación de Agricultura Ecológica; personal communication to J.P.C.) is also an alternative or complementary approach. Yet the need for field-testing in (possibly non-local) environments corresponding to future conditions may go beyond local capacities and thus may be in need of additional support from governmental and non-governmental organizations.

Fostering the prevention or control of burning outside and inside production forests, while maintaining wide buffer zones, may be necessary. Although some enterprises in 
Brazil dedicated to long-term timber production have fully implemented guidelines aimed at protecting the forest from fires (Pokorny et al. 2005), results are nevertheless varied. Fire management in the context of timber production seems to remain of low priority in other parts of the Amazon (e.g. Gould et al. 2002) while in Guatemala, fires intruding production forests appear to be effectively controlled due to sustained, participatory prevention and mitigation efforts (Nittler and Tschinkel 2005). Institutional, governance, and technical issues are equally important in fire management and prevention and the right balance among these will be dictated by specific site conditions (Barlow and Peres 2004). Generic approaches to fire management and prevention are already in place (e.g. FAO 2006b) and waiting for local modification.

One of the reasons why global policy has had little effect in incorporating climate change into tropical forestry may be because of the often controversial, multi-faceted nature of international policy making on forests themselves (see e.g. Persson 2005). This in turn has prevented the global carbon market to significantly influence the area under tree plantations established through the CDM; and to date, natural forest management is not yet eligible under the CDM. Nevertheless, discussions under the UNFCCC are currently dealing with establishing an international instrument to curb carbon emissions from tropical deforestation. Among several alternatives, the role of the international carbon market is being considered in the debate (Moutinho et al. 2005; Gullison et al. 2007). Although many methodological issues still need to be agreed upon, the reduction of carbon emissions from deforestation could present an opportunity for further implementing or else adjusting management practices to enhance the adaptive capacity of production forests to climate change. For example, fostering the application of carbon-retentive, RIL guidelines (Pinard and Putz 1996; Pinard and Cropper 2000).

Developing and implementing adaptation strategies for tropical forests may also necessitate institutional interventions aimed at raising the awareness of society about current and/or future climate changes. Climate change risks are seldom perceived by foresters, forest managers, or those forest-dependent communities in tropical latitudes. For most of them, climate change may represent a continuation of existing challenges and environmental stresses (Rojas 2004) and even if they acknowledge climate-related risks, changing attitudes may not be straightforward (see e.g. Wesche et al. 2006 for a temperate example). A study along the lines of Williamson et al. (2005) aimed at assessing the perceptions of climate change risk in temperate forests could be useful in the context of tropical forestry by helping to formulate future management options and policy development at the national or local level.

\section{Conclusions}

Current tropical forest management practices are based on the assumption that the climate will not vary to the extent that long-term productivity (and profitability) may be affected. Clearly, the selection of adaptation options is sometimes difficult because of the uncertainties regarding projections of future climate change (e.g. Dessai and Hulme 2007). However, more effort and resources seem to have been devoted at detecting the impacts of global climate change on protected tropical forests (reviewed in Clark 2007) than on maintaining their adaptive capacity as production systems. In advancing the incorporation of climate change considerations into tropical forestry, we foresee that at least two big challenges will have to be met. 
First, we consider that mainstreaming adaptation into national development and planning programs is a prerequisite for adequate action to cope with current and future climate change impacts. There is already guidance on this (Lim and Spanger-Siegfried 2005; Thompkins et al. 2005) that can be applied to the tropical forestry sector. In addition, and as the impacts of climate change also threaten the economic development of other sectors, many of which depend on the provision of forest goods and services, tropical forestry could benefit from being explicitly included into broader adaptation policies. As an example, among the 20 National Adaptation Programmes of Action (NAPAs) prepared by Least Developed Countries (LDCs) under the UNFCCC, at least 16 of them mention forestry projects within their adaptation priorities (http://unfccc.int/adaptation/napas/items/2679. php; accessed on 21 August 2007). The inclusion of forest ecosystems within NAPAs has been prominent due to their relatively high importance for local livelihoods (e.g. water regulation, food and fuelwood sources) and for the protection of coastlines (however, LDCs may still need guidance on how to enhance the adaptive capacity of their forests). Tropical forestry in the context of adaptation to climate change could also be made more prominent if the NAPA approach is extrapolated beyond that of LDCs.

The second challenge is a financial one, as adaptation entails a cost. In some cases, the private sector may decide to invest in adaptation measures, purely on the basis of commercial self-interest (e.g. modifications to tree improvement programs) although this will only come about if it has access to sound information on risks and associated costs. In other cases, government agencies could require the implementation of practical measures aimed at enhancing the adaptive capacity of forests as a condition for granting management concessions. However, funding of climate adaptation measures that generate wider public benefits of only indirect interest to industry or that are aimed at smallholders or other vulnerable groups may require alternative financing mechanisms which may not be currently available. The scarcity of funding underscores the importance of ensuring that adaptation measures are incorporated in the formulation and implementation of national and international initiatives concerned with forests, from broader policy interventions to local research and development projects.

Acknowledgements We thank Johnson Nkem, John Parrotta and Doug Sheil for comments on previous versions as well as the suggestions from anonymous reviewers. Also Mark Schulze, Mark Cochrane, and Jimmy Grogan provided initial insight. G.A.S. acknowledges the National Science and Engineering Research Council of Canada (NSERC), the Social Sciences and Humanities Research Council of Canada (SSHRC), and the Inter American Institute for Global Change Research (IAI) CNR II \# 021 which is supported by the US National Science Foundation (Grant GEO-045325).

Open Access This article is distributed under the terms of the Creative Commons Attribution Noncommercial License which permits any noncommercial use, distribution, and reproduction in any medium, provided the original author(s) and source are credited.

\section{References}

Adger WN, Huq S, Brown K, Conway D, Hulme M (2003) Adaptation to climate change in the developing world. Prog Dev Stud 3:179-195

Adger WN, Arnell NW, Thompkins EL (2005) Successful adaptation to climate change across scales. Glob Environ Change 15:77-86 
Barlow J, Peres CA (2004) Ecological responses to El Niño-induced surface fires in central Brazilian Amazonia: management implications for flammable tropical forests. Phil Trans R Soc Lond B 359:367-380

Bastien Y, Aussenac G, Frochot H (2000) Les changements climatiques: conséquences pour la sylviculture. Revue Forestière Française 52:129-137

Blate GM (2005) Modest tradeoffs between timber management and fire susceptibility of a Bolivian semideciduous forest. Ecol App 15:1649-1663

Boshier DH, Henson M (1997) Variación genética. In: Boshier DH, Lamb AT (eds) Cordia alliodora. Genética y mejoramiento de árboles. Oxford Forestry Institute, Tropical Forestry Papers 36, Oxford, pp 43-70

Brown FI, Schroeder W, Setzer A, de Los Rios Maldonado M, Pantoja N, Duarte A, Marengo J (2006) Monitoring fires in Southwestern Amazonia rain forests. EOS, Trans Am Geophys Union 87:253-259

CCBA (2005) Climate, Community, and Biodiversity Project Design Standards (First Edition). Washington, DC, Climate, Community and Biodiversity Alliance, May 2005. Available at: www.climate-standards.org

Callaway JM (2004) Adaptation benefits and costs: are they important in the global policy picture and how can we estimate them. Glob Environ Change 14:273-282

Carter TR, Parry ML, Harasawa H, Nishioka S (1994) IPCC Technical Guidelines for Assessing Climate Change Impacts and Adaptations with a Summary for Policy Makers and a Technical Summary. Department of Geography, University College London, UK and the Center for Global environmental Research, National Institute for Environmental Studies, Japan

Cedeño L, Carrero C, Franco W, Torres-Lezama A (2001) Sphaeropsis sapinea asociado con quema del cogollo, muerte regresiva y cáncer en troncos, ramas y raíces del pino caribe en Venezuela. Interciencia 26:210-215

Christensen JH, Hewitson B, Busuioc A, Chen A, Gao X, Held I, Jones R, Kolli RK, Kwon WT, Laprise R, Magaña Rueda V, Mearns L, Menéndez CG, Räisänen J, Rinke A, Sarr A, Whetton P (2007) Regional climate projections. In: Climate Change 2007: The physical science basis. Contribution of Working Group I to the Fourth Assessment Report of the Intergovernmental Panel on Climate Change. Cambridge University Press, Cambridge, pp 847-940

Clark DA (2007) Detecting tropical forests' responses to global climatic and atmospheric change: current challenges and a way forward. Biotropica 39:4-19

Cochrane MA (2001) Synergistic interactions between habitat fragmentation and fire in evergreen tropical forests. Conserv Biol 15:1515-1521

Colinvaux PA, De Oliveira PE, Moreno JE, Miller MC, Bush MB (1996) A long pollen record from lowland Amazonia: forest and cooling in glacial times. Science 274:85-88

Colinvaux PA, De Oliveira PE, Bush MB (2000) Amazonian and neotropical plant communities on glacial time-scales: the failure of the aridity and refuge hypotheses. Quat Sci Rev 19:141-169

Cordero J, Boshier D H (eds) (2003) Arboles de Centroamérica. Oxford Forestry Institute, Oxford. CATIE, Costa Rica

Cornelius JP, Mesén JF, Correa EA, Henson M (1996) Variation in growth and form of Alnus acuminata Kunth. in Costa Rica. Silvae Genetica 45:24-30

Cornelius JP, Clement CR, Weber JC, Sotelo-Montes C, Van Leeuwen J, Ugarte-Guerra LJ, RicseTembladera A, Arévalo-López L (2006) The trade-off between genetic gain and conservation in a participatory improvement programme: the case of peach palm (Bactris gasipaes Kunth). For Trees and Livelihoods 16:17-34

Cox PM, Betts RA, Collins M, Harris PP, Huntingford C, Jones CD (2004) Amazonian forest dieback under climate-carbon cycle projections for the 21st century. Theor App Clim 78:137-156

Dessai S, Hulme M (2007) Assessing the robustness of adaptation decisions to climate change uncertainties: a case study on water resources management in the East of England. Glob Environ Change 17:59-72

Dixon RK, Brown S, Houghton RA, Solomon AM, Trexler MC, Wisniewki J (1994) Carbon pools and flux of global forest ecosystems. Science 263:185-190

Drever CR, Peterson G, Messier C, Bergeron Y, Flanningan M (2006) Can forest management based on natural disturbances maintain ecological resilience? Can J For Res 36:2285-2299

Dykstra DP, Heinrich R (1996) FAO model code of forest harvesting practice. Food and Agriculture Organization of the United Nations, Rome, Italy

Falconer DS (1989) Introduction to quantitative genetics, 3rd edn. Wiley, New York

FAO (2006a) Global Forest Resources Assessment 2005. FAO Forestry Paper 147, Rome

FAO (2006b) Fire management: voluntary guidelines. Fire Management Working Paper 17, Rome

Federov AV, Philander SG (2000) Is El Niño changing? Science 288:1997-2002

Feely KJ, Wright SJ, Nur Supardi MN, Kassim AR, Davies SJ (2007) Decelerating growth in tropical forest trees. Ecol Lett 10:1-9

Fredericksen TS, Pariona W (2002) Effect of skidder disturbance on commercial tree regeneration in logging gaps in a Bolivian tropical forest. For Ecol Manage 171:223-230 
Fredericksen TS, Putz FE (2003) Silvicultural intensification for tropical forest conservation. Biodivers Conserv 12:1445-1453

Gibson GL, Barnes RD, Berrington J (1983) Provenance productivity in Pinus caribaea and its interaction with environment. Commonw For Rev 62:93-106

Gitz V, Ciais P (2004) Future expansion of agriculture and pasture acts to amplify atmospheric $\mathrm{CO}_{2}$ levels in response to fossil-fuel and land-use change emissions. Clim Change 67:161-184

Gould KA, Fredericksen TS, Morales F, Kennard D, Putz FE, Mostacedo B, Toledo M (2002) Post-fire tree regeneration in lowland Bolivia: implications for fire management. For Ecol Manage 165:225-234

Grant PR, Grant BR (1995) Predicting microevolutionary responses to directional selection on heritable variation. Evolution 49:241-251

Greaves A (1978) Descriptions of seed sources and collections for provenances of Pinus caribaea. Commonwealth Forestry Institute Tropical Forestry Paper 11, Oxford

Grogan J, Barreto P (2005) Big-leaf mahogany on CITES Appendix II: big challenge, big opportunity. Conserv Biol 19:973-976

Grogan J, Galvão J (2006) Factors limiting post-logging seedling regeneration by big-leaf mahogany (Swietenia macrophylla) in Southeastern Amazonia, Brazil, and implications for sustainable management. Biotropica 38:219-228

Grogan J, Landis RM, Ashton MS, Galvão J (2005) Growth response by big-leaf mahogany (Swietenia macrophylla) advance seedling regeneration to overhead canopy release in southeast Pará, Brazil. For Ecol Manage 204:399-412

Guariguata MR, Sáenz GP (2002) Post logging acorn production and oak regeneration in a tropical montane forest, Costa Rica. For Ecol Manage 167:285-293

Gullison RE, Frumhoff PC, Cannadell JG, Field CB, Nepstad DC, Hayhoe K, Avissar R, Curran LM, Friedlingstein P, Jones CD, Nobre C (2007) Tropical forests and climate policy. Science 316:985-986

Hartley MJ (2002) Rationale and methods for conserving biodiversity in plantation forests. For Ecol Manage 155:81-95

Hodge GR, Dvorak WS, Romero JL (2001) Growth and provenance variation of Pinus caribaea var. hondurensis as an exotic species. S Afr For J 190:43-51

Hodge GR, Dvorak WS, Urueña H, Rosales L (2002) Growth, provenance effects and genetic variation of Bombacopsis quinata in field tests in Venezuela and Colombia. For Ecol Manage 158:273-289

Holdsworth AR, Uhl C (1997) Fire in Amazonian selectively logged rain forest and the potential for fire reduction. Ecol App 7:713-725

Hollingsworth PM, Dawson IK, Goodall-Copestake WP, Richardson JE, Weber JC, Sotelo-Montes C, Pennington RT (2005) Do farmers reduce genetic diversity when they domesticate tropical trees? A case study from Amazonia. Mol Ecol 14:497-501

IISD (2006) Report of the Wilton Park Conference on "Forestry: a sectoral response to climate change" [http://www.iisd.ca/ymb/forest/srcc/]; accessed on 29 January 2007. International Institute for Sustainable Development

Innes JL, Hickey GM (2006) The importance of climate change when considering the role of forests in the alleviation of poverty. Int For Rev 8:406-416

Innes JL, Edwards IK, Wilford DJ (eds) (2005) Forests in the balance: linking tradition and technology. Abstracts XXII IUFRO World Congress. International Forestry Review 5

IPCC (1996) Climate change 1995. Impact, adaptation and mitigation of climate change: scientific-technical analyses. Cambridge University Press, Cambridge

IPCC (2000) Land use, land use change and forestry. Cambridge University Press, Cambridge

IPCC (2001) Climate change 2001: Impact, adaptation and vulnerability. Cambridge University Press, Cambridge

IPCC (2007a) Climate change 2007: the physical science basis. Summary for Policymakers. Contribution of working group I to the fourth assessment report of the intergovernmental panel on climate change. IPCC Secretariat, Geneva

IPCC (2007b) Climate change 2007: climate change impacts, adaptation and vulnerability. Summary for Policymakers. Working II Group Contribution to the Intergovernmental Panel on Climate Change Fourth Assessment Report. IPCC Secretariat, Geneva

ITTO (2006) Status of tropical forest management 2005. ITTO Technical Series no. 24. Yokohama, Japan

Jactel H, Brockerhoff E, Duelli P (2005) A test of the biodiversity-stability theory: meta -analysis of tree species diversity effects on insect pest infestations, and examination of responsible factors. In: SchererLorenzen M, Körner Ch, Schulze E-D (eds) Forest diversity and Function: Temperate and Boreal Systems. Ecological Studies vol. 176. Springer-Verlag, Berlin, pp 235-262

Johns JS, Barreto P, Uhl C (1996) Logging damage during planned and unplanned logging operations in the eastern Amazon. For Ecol Manage 89:59-71 
Keller M, Asner G, Blate G, McGlockling J, Merry F, Peña-Claros M, Zweede J (2007) Timber production in selectively logged tropical forests in South America. Frontiers in Ecology and the Environment 5:213-216

Kelty MJ (2006) The role of species mixtures in plantation forestry. For Ecol Manage 233:195-204

Lamb D (1998) Large-scale ecological restoration of degraded lands: the potential role of timber plantations. Restor Ecol 6:271-279

Lamb D, Erskine PD, Parrotta JA (2005) Restoration of degraded tropical forest landscapes. Science 310:1628-1632

Lambin EF, Turner BL, Geist HJ, Agbola SB, Angelsen A, Bruce JW, Coomes OT, Dirzo R, Fischer G, Folke C, George PS, Homewood K, Imbernon J, Leemans R, Li X, Moran EF, Mortimore M, Ramakrishnan PS, Richards JF, Skånes H, Steffen W, Stone GD, Svedin U, Veldkamp TA, Vogel C, Xu J (2001) The causes of land-use and land-cover change: moving beyond the myths. Glob Environ Change $11: 261-269$

Laurance WF (2004) Forest-climate interactions in fragmented tropical landscapes. Phil Trans R Soc Lond B 359:345-352

Laurance WF, Peres CA (eds) (2006) Emerging threats to tropical forests. University of Chicago Press, Chicago

Laurance WF, Oliveira AA, Laurance SG, Condit R, Nascimento HEM, Sanchez-Thorin AC, Lovejoy TE, Andrade A, D'Angelo S, Ribeiro JE, Dick CW (2004) Pervasive alteration of tree communities in undisturbed Amazonian forests. Nature 428:171-174

Le Corre V, Kremer A (2003) Genetic variability at neutral markers, quantitative trait loci and trait in a subdivided population under selection. Genetics 164:1205-1219

Ledig FT, Kitzmiller JH (1992) Genetic strategies for reforestation in the face of global climate change. For Ecol Manage 50:153-169

Lewis SL (2006) Tropical forests and the changing earth system. Phil Trans R Soc B 361:195-210

Lewis S, Phillips OL, Baker TR, Lloyd J, Malhi Y, Almeida S, Higuchi N, Laurance WF, Neill DA, Silva JNM, Terborgh J, Torres-Lezama A, Vázquez Martínez R, Brown S, Chave J, Kuebler C, Núñez Vargas P, Vinceti B (2004) Concerted changes in tropical forest structure and dynamics: evidence from 50 South American long-term plots. Phil Trans R Soc Lond B 359:421-436

Lewis SL, Phillips OL, Baker TR (2006) Impacts of global change on the structure, dynamics, and functioning of South American tropical forests. In: Laurance WF, Peres CA (eds) Emerging threats to tropical forests. University of Chicago Press, Chicago, pp 15-31

Lim B, Spanger-Siegfried E (eds) (2005) Adaptation policy frameworks for climate change: developing strategies, policies and measures. Cambridge University Press, Cambridge

Malhi Y, Wright J (2004) Spatial patterns and recent trends in the climate of tropical rainforest regions. Proc R Soc Lond B 359:311-329

Markham A (ed) (1998) Potential impacts of climate change on tropical forest ecosystems. Kluwer, Dordrecht

McKay JK, Latta RG (2002) Adaptive population divergence: markers, QTL and traits. Trends Ecol Evol 17:285-291

Mesén FJ, Boshier DH, Cornelius JP (1993) Genetic improvement of trees in Central America, with particular reference to Costa Rica. In: Leakey RRB, Newton AC (eds) Tropical Trees: the potential for domestication and the rebuilding of forest resources. HMSO, London, pp 249-255

Morley RJ (2000) Origin and evolution of tropical rain forests. John Wiley, England

Moutinho P, Santilli M, Schwartzman S, Rodrigues L (2005) Why ignore tropical deforestation? A proposal for including forest conservation in the Kyoto Protocol. Unasylva 222:27-30

Navarro C, Ward S, Hernández M (2002) The tree Cedrela odorata (Meliaceae): a morphologically subdivided species in Costa Rica. Revista de Biologia Tropical 50:21-29

Neelin JD, Münnich M, Su H, Meyerson JE, Holloway CE (2006) Tropical drying trends in global warming models and observations. Proc Natl Acad Sci USA 103:6110-6115

Nepstad D, Lefebvre P, Lopes da Silva U, Tomasella J, Schlesinger P, Solorzano L, Moutinho P, Ray D, Guerreira Benito J (2004) Amazon drought and its implications for forest flammability and tree growth: a basin-wide analysis. Glob Change Biol 10:704-717

Nichols JD, Bristow M, Vanclay JK (2006) Mixed-species plantations: Prospects and challenges. For Ecol Manage 233:383-390

Nikles DG, Spidy T, Rider EJ, Eissemann RL, Newton RS, Frederick M (1983) Genetic variation in windfirmness among provenances of Pinus caribaea Mor. var. hondurensis Barr. and Golf. in Queensland. Silvicultura 8:124-130

Nittler J, Tschinkel H (2005) Community forest management in the maya biosphere reserve of Guatemala: Protection through profits. U.S. Agency for International Development (USAID) and Sustainable Agriculture and Natural Resource Management (SANREM), University of Georgia, USA

Noss RF (2001) Beyond Kyoto: forest management in a time of rapid climate change. Conserv Biol 15:578-590 
Parrotta JA, Maître H-F, Auclair D, Lafond M-H (eds) (2005) Extended abstracts from the conference in Montpellier, France, June 14-18, 2004, on "Meeting the challenge: silvicultural research in a changing world". IUFRO World Series vol. 15. Vienna, Austria

Penman J, Gytarsky M, Hiraishi T, Krug T, Kruger D, Pipatti R, Buendia L, Miwa K, Ngara T, Tanabe K, Wagner F (2003) Good practice guidance for land-use, land-use change and forestry. Intergovernmental panel on climate change-national greenhouse gas inventories programme. Institute for Global Environmental Strategies, Japan

Persson R (2005) Where is the United Nations Forum on forests going? Int For Rev 7:348-357

Petit RJ, Hampe A (2006) Some evolutionary consequences of being a tree. Ann Rev Ecol Syst 37:187-214

Petit B, Montagnini F (2006) Growth in pure and mixed plantations of tree species used in reforesting rural areas of the humid region of Costa Rica, Central America. For Ecol Manage 233:338-343

Phillips OL, Vásquez R, Arroyo L, Baker TR, Killeen T, Lewis SL, Malhi Y, Monteagudo A, Neill D, Nuñez P, Alexiades M, Cerón C, Di Fiore A, Erwin T, Jardim A, Palacios W, Saldias M, Vincenti B (2002) Increasing dominance of large lianas in Amazonian forests. Nature 418:770-773

Phillips OL, Vázquez Martínez R, Monteagudo Mendoza A, Baker TR, Núñez Vargas P (2005) Large lianas as hyperdinamic elements of the tropical forest canopy. Ecology 86:1250-1258

Pinard MA, Cropper WP (2000) Simulated effects of logging on carbon storage in dipterocarp forest. J App Ecol 37:267-283

Pinard MA, Putz FE (1996) Retaining forest biomass by reducing logging damage. Biotropica 28:278-295

Pinard MA, Putz FE, Licona JC (1999) Tree mortality and vine proliferation following a wildfire in a subhumid tropical forest in eastern Bolivia. For Ecol Manage 116:247-252

Pitman NCA, Terborgh JW, Silman MR, Nuñez VP, Neill DA, Cerón CE, Palacios WA, Aulestia M (2001) Dominance and distribution of tree species in upper Amazonian terra firme forests. Ecology 82:2101-2117

Pokorny B, Sabogal C, Silva JNM, Bernardo P, Souza J, Zweede J (2005) Compliance with reduced-impact harvesting guidelines by timber enterprises in terra firme forests of the Brazilian Amazon. Int For Rev 7:9-20

Pounds JA, Bustamante MR, Coloma LA, Consuegra JA, Fogden MPL, Foster PN, La Marca E, Masters KL, Merino-Viteri A, Puschendorf R, Ron SRG, Sánchez-Azofeifa A, Still CJ, Young BE (2006) Widespread amphibian extinctions from epidemic disease driven by global warming. Nature 439:161-167

Rojas AV (2004) Comprehensive environmental projects: Linking adaptation to climate change, sustainable land use, biodiversity conservation and water management. Both Ends, The Netherlands

Sáenz-Romero C, Guzmán-Reyna RR, Rehfeldt GE (2006) Altitudinal genetic variation among Pinus oocarpa populations in Michoacán, Mexico: implications for seed zoning, conservation, tree breeding and global warming. For Ecol Manage 229:340-350

Salinger MJ (2005) Climate variability and climate change: past, present and future. Clim Change 70:9-29

Scholes R, Linder S (1998) Chapter 12: Forests. In: Feenstra J, Burton I, Smith J, Tol R (eds) Handbook on methods for climate change impact assessment and adaptation strategies. UNEP-Vrije Universiteit, Ámsterdam

Scholze M, Knorr W, Arnell NW, Prentice IC (2006) A climate-change risk analysis for world ecosystems. Proc Nat Acad Sci 103:13116-13120

Schulze M (2008) Technical and financial analysis of enrichment planting in logging gaps as a potential component of forest management in the eastern Amazon. For Ecol Manage. DOI 10.1016/ j.foreco.2007.09.082

Schulze M, Grogan J, Vidal E (2008) Technical challenges to sustainable forest management in concessions on public lands in the Brazilian Amazon. J Sustain For 26

Shukla J, Nobre C, Sellers P (1990) Amazon deforestation and climate change. Science 247:1322-1325

Simons AJ, Leakey RRB (2004) Tree domestication in tropical agroforestry. Agrofor Syst 61:167-181

Simons AJ, MacQueen DJ, Stewart JL (1994) Strategic concepts in the domestication of non-industrial trees. In: Leakey RRB, Newton AC (eds) Tropical trees: the potential for domestication and the rebuilding of forest resources. London, HMSO, pp 91-102

Sist P (2000) Reduced impact logging in the tropics: objectives, principles and impacts. Int For Rev 2:3-10

Snook LK, Negreros-Castillo P (2004) Regenerating mahogany (Swietenia macrophylla King) on clearings in Mexico's Maya forest: the effects of clearing method and cleaning on seedling survival and growth. For Ecol Manage 189:143-160

Sohngen B, Mendelsohn R, Sedjo R (2001) A global model of climate change impacts on timber markets. J Agric Resour Econ 26:326-343

Sotelo Montes C, Weber JC (1997) Priorización de especies arbóreas para sistemas agroforestales en la Selva Baja del Perú. Agroforestería en las Américas 4:12-17

Sunderlin WD, Angelsen A, Belcher B, Burgers P, Nasi R, Santoso L, Wunder S (2005) Livelihoods, forests, and conservation in developing countries: an overview. World Dev 33:1383-1402 
Thomas DSG, Twyman C (2005) Equity and justice in climate change adaptation amongst natural resource dependent societies. Glob Environ Change 15:115-124

Thompkins EL, Nicholson-Cole SA, Hurlston L-A, Boyd E, Brooks Hodge G, Clarke J, Gray G, Trotz N, Varlack L (2005) Surviving climate change in small islands-a guidebook. Tyndall Centre for Climate Change Research. School of Environmental Sciences, University of East Anglia, United Kingdom

Timmermann A, Oberhuber J, Bacher A, Esch M, Latif M, Roeckner E (1999) Increased El Niño frequency in a climate model forced by future greenhouse warming. Nature 98:694-697

Valle D, Schulze M, Vidal E, Grogan J, Sales M (2006) Identifying bias in stand-level growth and yield estimations: a case study in eastern Brazilian Amazonia. For Ecol Manage 236:127-135

Varmola M, Gautier D, Lee DK, Montagnini F, Saramäki J (2005) Diversifying functions of planted forests. In: Mery G, Alfaro R, Kanninen M, Lobovikov M (eds) Forests in the global balance-changing paradigms. IUFRO World Series vol. 17. Vienna, Austria

Verissimo A, Cochrane MA, Souza C Jr (2002) National forests in the Amazon. Science 297:1478

Vozzo JA (ed) (2002) Tropical tree seed manual. United States Department of Agriculture Forest Service. Agriculture Handbook 721. Washington, DC

Weber JC, Labarta Chávarri RL, Sotelo Montes C, Brodie AW, Cromwell E, Schreckenberg K, Simons AJ (1997) Farmers' use and management of tree germplasm: case studies from the Peruvian Amazon. In: Simons AJ, Kindt R, Place F (eds) Proceedings of an International Workshop on Policy Aspects of Tree Germplasm Demand and Supply, ICRAF, Nairobi, Kenya, 6-8 October 1997, pp 57-63

Weber JC, Sotelo Montes C, Vidaurre H, Dawson IK, Simons AJ (2001) Participatory domestication of agroforestry trees: an example from the Peruvian Amazon. Dev Prac 11:425-433

Wesche S, Kirby K, Ghazoul J (2006) Plant assemblages in British beech woodlands within and beyond native range: implications of future climate change for their conservation. For Ecol Manage 236:385392

Williamson TB, Parkins JR, McFarlane BL (2005) Perceptions of climate change risk to forest ecosystems and forest based communities. For Chron 81:710-716

Wolffsohn A (1984) Estudios silviculturales de Pinus oocarpa Schiede en la República de Honduras. Publicación Miscelánea 4, Escuela Nacional de Ciencias Forestales. Siguatepeque, Honduras

Wright SJ, Calderón O, Hernández A, Paton S (2004) Are lianas increasing in importance in tropical forests? A 17-year record from Panamá. Ecol 85:484-489

Yeh FC (2000) Population genetics. In: Young A, Boshier D, Boyle T (eds) Forest conservation genetics. CABI Publishing, Wallingford, pp 21-37 